\title{
Behaviour of Low-Symmetry Crown-Phthalocyanine in Solution: Concentration Aggregation vs. Cation-Induced Assembly
}

\author{
Alexander G. Martynov, ${ }^{a} @$ Maria V. Panova, ${ }^{\mathrm{b}}$ Yulia G. Gorbunova, ${ }^{\mathrm{a}, \mathrm{c}}$ \\ and Aslan Yu. Tsivadze ${ }^{a, c}$ \\ Dedicated to Full member of Russian Academy of Sciences, Prof. O.N. Chupakhin \\ on the occasion of his $80^{\text {th }}$ Anniversary
}

\begin{abstract}
${ }^{a}$ A.N. Frumkin Institute of Physical Chemistry and Electrochemistry, Russian Academy of Sciences, 119071 Moscow, Russia ${ }^{\mathrm{b}}$ Higher Chemical College, Russian Academy of Sciences, 125047 Moscow, Russia

${ }^{\mathrm{c}}$ N.S. Kurnakov Institute of General and Inorganic Chemistry, Russian Academy of Sciences, 119991 Moscow, Russia

${ }^{\circledR}$ Corresponding authorE-mail: martynov.alexandre@gmail.com
\end{abstract}

\begin{abstract}
Statistical condensation of 4',5'-dicyanobenzo-15-crown-5 and 4,5-dibutoxyphthalonitrile in the presence of $\mathrm{Mg}^{2+}$ as a template led to a mixture of complexes, which was separated to isolate mono-crown-substituted magnesium phthalocyaninate $\mathrm{Mg}\left[(15 \mathrm{C5})(\mathrm{BuO})_{6} \mathrm{Pc}\right]$. Its demetallation afforded corresponding metal-free ligand, $\mathrm{H}_{2}\left[(15 \mathrm{C5})(\mathrm{BuO})_{6} \mathrm{Pc}\right]$. Aggregation of this phthalocyanine was studied both in concentrated solutions (up to $1.32 \cdot 10^{-3} \mathrm{M}$ in chloroform), or in the presence of potassium acetate. Application of nonlinear regression for analysis of spectrophotometric data provided evidences of dimerization of phthalocyanine molecules under these conditions. Architecture of dimers is discussed.
\end{abstract}

Keywords: Low symmetry phthalocyanine, crown ether, supramolecular chemistry, aggregation, UV-Vis spectroscopy, calculations of stability constant, ChemEqui software.

\section{Поведение несимметричного краун-замещенного фталоцианина в растворе: концентрационная и катион-инАуцированная агрегация}

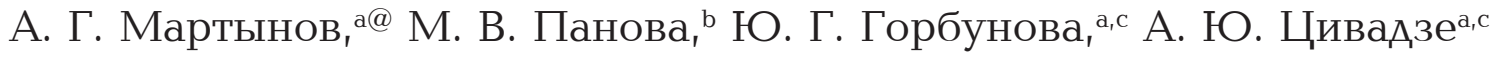 \\ Посвящается Академику РАН профессору О.Н. Чупахину по случаю его 80-летнего юбилея \\ ${ }^{\mathrm{a}}$ ФБУН Институт физической химии и электрохимии им. А.Н. Фрумкина РАН, Москва 119071, Россия \\ ${ }^{\mathrm{b}}$ Высший химический колледж Российской академии наук, 125047 Москва, Россия \\ ' ФГБУН Институт общей и неорганической химии им. Н.С. Курнакова РАН, 119991 Москва, Россия \\ @E-mail: martynov.alexandre@gmail.com
}

\begin{abstract}
Методом статистической конденсации 4',5'-дищианобензо-15-краун-5 и 4,5-дибутоксифталонитрила в присутствии $\mathrm{Mg}^{2+}$ в качестве темплата была получена смесь комплексов, из которой был выделен монокраун-замещченный фталоччианинат магния $\mathrm{Mg}\left[(15 \mathrm{C5})(\mathrm{BuO}){ }_{6} \mathrm{Pc}\right]$, деметаллированием которого был получен соответствующий лиганд, $\mathrm{H}_{2}\left[(15 \mathrm{C5})(\mathrm{BuO}){ }_{6} \mathrm{Pc}\right]$. Исследование агрегации этого фталочиианина проводилось как в концентрированных растворах (до 1.32·10 С использованием методов нелинейной регрессии для анализа данных электронной спектроскопии поглощения было установлено, что в обоих случаях происходит димеризация фтталоиианина. В работе обсуждается предполагаемое строение образующихся димеров.
\end{abstract}

Ключевые слова: Несимметричный фталоцианин, краун-эфир, супрамолекулярная химия, агрегация, электронная спектроскопия поглощения, расчет констант устойчивости, программа ChemEqui. 


\section{Introduction}

Physical-chemical characteristics of functional supramolecular materials based on phthalocyanines and their analogues are strongly influenced by intermolecular interactions, which in turn depend on mutual orientation of molecules. ${ }^{[1]}$ Therefore, investigation of novel molecular blocks - substituted phthalocyanines, capable of formation of ordered supramolecular assemblies, is an important task.

Among such blocks special attention is paid to crownsubstituted phthalocyanines. ${ }^{[2-4]}$ In the presence of alkalimetal ions they form supramolecular assemblies of various architecture, depending on nature of both receptor and substrate. Since architecture of these assemblies affects their physical-chemical properties, this approach can be used to obtain supramolecular materials with desired functional characteristics. ${ }^{[5-7]}$

Another approach to functionalized phthalocyanines implies synthesis of low-symmetry molecules, composed of different isoindole fragments. ${ }^{[8-10]}$ Such molecules can be used as molecular blocks of supramolecular assemblies ${ }^{[11-13]}$ and components of nonlinear optical devices and materials. ${ }^{[14]}$

Typically, low-symmetry phthalocyanines are prepared by template condensation of two (or even more) phthalonitriles mixed in solution or in melt, leading to mixture of all possible complexes (Figure 1). Their distribution will be driven by relative reactivity of starting phthalonitriles and will be close to distribution defined by Newton binomial if reactivity of these precursors is similar (Figure 2) ${ }^{[15]}$ In the case when reactivity of starting nitriles is different, distribution of reaction products can significantly deviate from binomial. ${ }^{[16]}$

Figure 2 shows that even large excess of one of nitriles in cross-condensation cannot prevent formation of mixture of complexes. Therefore, the problem of products separation arises, which is typically solved by chromatographic methods.

The structure of low-symmetry phthalocyanines, formed in mixed condensation, depends on nature of metal ion, used as a template. For example, REE ions are known to be templates for synthesis of sandwich complexes. ${ }^{[17-19]}$ By means of it, reaction of unsubstituted phthalonitrile and 4',5'-dicyanobenzo-15-crown-5 (DCB15C5) in the presence of $\mathrm{Lu}(\mathrm{OAc})_{3}$ and $\mathrm{DBU}$ in refluxing hexanol, afforded complicated mixture of twenty one possible double-deckers, which could be partially separated by numerous chromatographic columns to isolate monocrown-substituted complex $[(15 \mathrm{C} 5) \mathrm{Pc}] \mathrm{Lu}(\mathrm{Pc})$ in $3 \%$ yield. ${ }^{[20,21]}$ Dimerization of this complex in the presence of KOAc was studied by ESR.

To decrease the number of possible double-decker complexes formed in mixed condensation, europium complex, already containing one unsubstituted Pc ligand - $(\mathrm{Pc}) \mathrm{Eu}(\mathrm{acac})$ was used as a template. Its reaction with DCB15C5, phthalonitrile and DBU in refluxing pentanol afforded only five crown-substituted heteroleptic doubledeckers $-\left[(15 \mathrm{C} 5)_{\mathrm{n}} \mathrm{Pc}\right] \mathrm{Eu}(\mathrm{Pc}), \mathrm{n}=1-4$, including two isomers for $n=2$. This mixture could be separated by column chromatography, the yields of individual complexes, characterized by UV-Vis, MCD and NMR spectra, were 5-13\%. ${ }^{[22]}$ Inter-

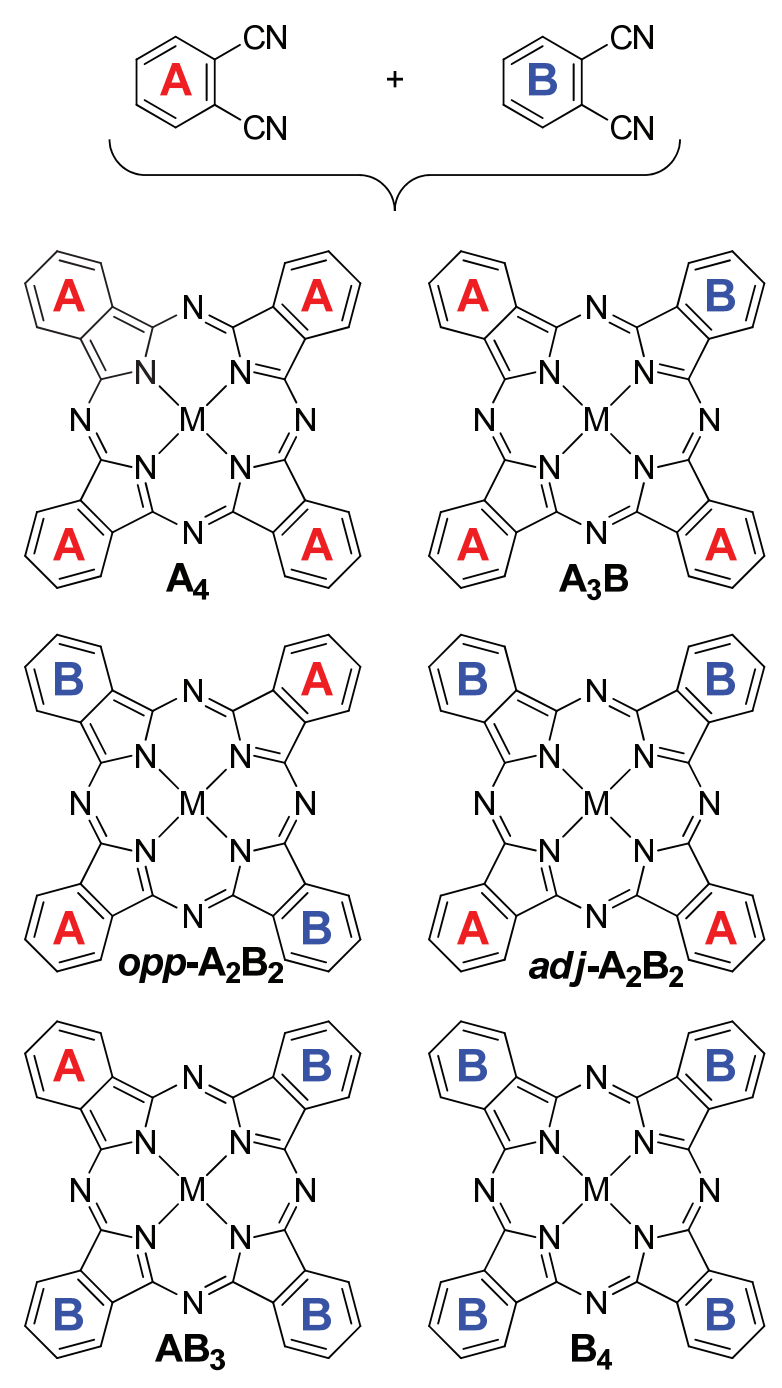

Figure 1. Low-symmetry phthalocyanines $\mathrm{A}_{3} \mathrm{~B}, \mathrm{~A}_{2} \mathrm{~B}_{2}$ (two isomers) and $\mathrm{AB}_{3}$ together with symmetrical $\mathrm{A}_{4}$ and $\mathrm{B}_{4}$ complexes, formed in mixed condensation of two phthalonitriles.

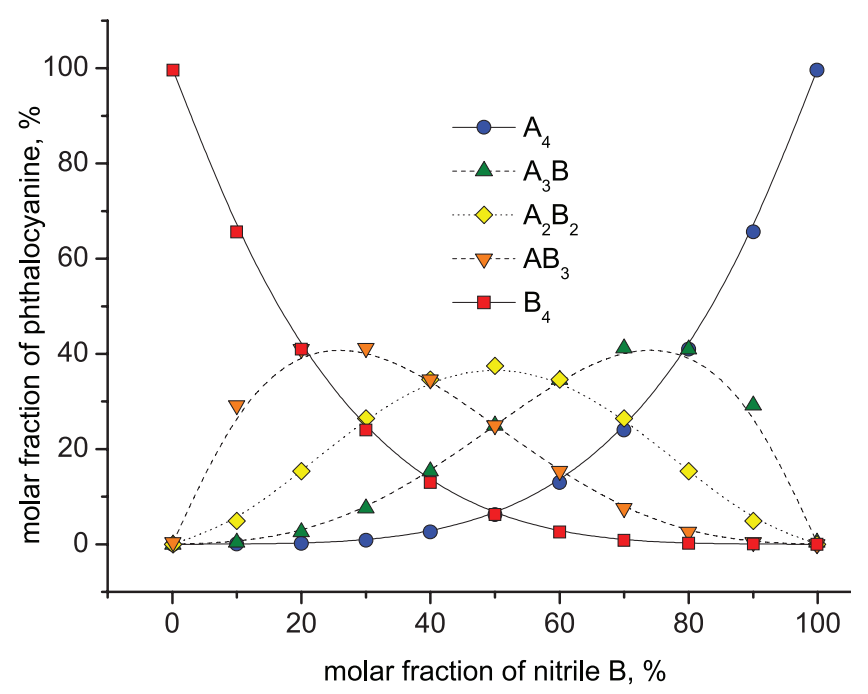

Figure 2. Calculated distribution of phthalocyanines in mixed condensation of phthalonitriles $\mathrm{A}$ and $\mathrm{B}$ with equivalent reactivity. 
action of complexes $\left[(15 \mathrm{C} 5)_{\mathrm{n}} \mathrm{Pc}\right] \mathrm{Eu}(\mathrm{Pc}), \mathrm{n}=2,3$ with excess of copper or zinc acetates in DMF afforded corresponding complexes $\mathrm{M}\left[(15 \mathrm{C} 5)_{\mathrm{n}} \mathrm{Pc}\right], \mathrm{M}=\mathrm{Cu}, \mathrm{Zn} \cdot{ }^{[23,24]}$ Aggregation of these complexes, induced by interaction with potassium ions, was studied by spectrophotometric titration. ${ }^{[23]}$

Phthalocyanines, containing two and more crownsubstituted fragments, exhibit good solubility in common organic solvents, while mono-crown-substituted complexes have only limited solubility. ${ }^{[25]}$ At the same time, such type of complexes are prominent components of highly ordered supramolecular assemblies, ${ }^{[11,13,26,27]}$ therefore synthesis of soluble compounds is required.

With this aim we have developed synthesis of lowsymmetry phthalocyanine $\mathrm{H}_{2}\left[(15 \mathrm{C} 5)(\mathrm{BuO})_{6} \mathrm{Pc}\right]$, bearing one 15 -crown-5 ring and six solubilizing $n$-butoxy groups, as a precursor to low-symmetry metal complexes.

\section{Experimental}

DCB15C5 and 4,5-dibutoxyphthalonitrile were synthesized according to previously reported procedures. ${ }^{[28,29]}$ Isoamyl alcohol was distilled over sodium under argon. DBU was dried and distilled over $\mathrm{CaH}_{2}$ in vacuum. Alumina (Merck) and silica (Macherey Nagel, Kieselgel 60) were used for chromatography. Chloroform was dried over $\mathrm{CaCl}_{2}$ and distilled over $\mathrm{CaH}_{2}$.

UV-vis spectra were measured on Varian Cary-100 spectrometer in quartz cells with $0.01-1 \mathrm{~cm}$ optical path. NMR spectra were recorded on Bruker Avance 600. NMR spectra were referenced on residual solvent signal. ${ }^{[30]}$ MALDI TOF mass-spectra were measured on Ultraflex spectrometer (Bruker Daltonics) with 2,5-dihydroxybenzoic acid (DHB), used as a matrix.

$M g\left[(15 C 5)(B u O)_{6} P c\right]:$ DCB15C5 (127 mg, $\left.0.4 \mathrm{mmol}\right), 4,5-$ dibutoxyphthalonitrile (545 mg, $2 \mathrm{mmol})$ and $\mathrm{Mg}(\mathrm{OAc})_{2}(171 \mathrm{mg}$, $1.2 \mathrm{mmol})$ were dissolved in $i-\mathrm{AmOH}(6 \mathrm{ml})$ and $\mathrm{DBU}(0.36 \mathrm{ml}$, $2.4 \mathrm{mmol}$ ) was added. Reaction mixture was refluxed under Ar for $24 \mathrm{~h}$. Then it was evaporated in vacuum and dark-green residue was sonicated with $25 \%$ aq. EtOH. Resulting green precipitate was filtered, washed with aq. EtOH and washed off the filter with $\mathrm{CHCl}_{3}$. Target complex was isolated by chromatography on silica: less polar $\mathrm{Mg}\left[(\mathrm{BuO})_{8} \mathrm{Pc}\right]$ was eluted by $\mathrm{CHCl}_{3}$ with $1-2$ vol. $\% \mathrm{MeOH}$, while more polar $\mathrm{Mg}\left[(15 \mathrm{C} 5)(\mathrm{BuO})_{6} \mathrm{Pc}\right]$ was eluted by $\mathrm{CHCl}_{3}$ with 2-10 vol.\% MeOH. Other complexes were absorbed on silica irreversibly. Target complex was obtained as a dark green powder (194 mg, $41 \%)$. UV-Vis $\left(\mathrm{CHCl}_{3}\right) \lambda_{\text {m }}$ nm (lge): 680 (5.11), 614 (4.47), 360 (4.93), 290 (4.75). NMR ${ }^{1} \mathrm{H}$ (DMSO-d $)_{6} \delta$ ppm: 0.93-0.95 (m, 18H, $\left.\mathrm{CH}_{2} \mathrm{CH}_{2} \mathrm{CH}_{2} \mathrm{CH}_{3}\right)$; $1.25,1.49,1.78\left(3 \mathrm{~m}, 24 \mathrm{H}, \mathrm{CH}_{2} \mathrm{CH}_{2} \mathrm{CH}_{2} \mathrm{CH}_{3}\right) ; 3.63-3.79,3.95-$ 4.13, 4.38-4.42 (3m, 28H, $\left.\mathrm{OCH}_{2}\right) ; 9.00,9.05,9.06\left(3 \mathrm{~s}, 8 \mathrm{H}, \mathrm{H}_{\mathrm{Ar}}\right)$. MALDI TOF MS, m/e: for $[\mathrm{M}]^{+}-\mathrm{C}_{64} \mathrm{H}_{78} \mathrm{MgN}_{8} \mathrm{O}_{11}$ calculated 1158.6, observed 1158.7, for $[\mathrm{M}+\mathrm{DHB}]^{+}-\mathrm{C}_{71} \mathrm{H}_{83} \mathrm{MgN}_{8} \mathrm{O}_{15}$ calculated 1311.6, observed 1311.9.

$\mathrm{H}_{2}\left[(15 \mathrm{C} 5)(\mathrm{BuO})_{6} \mathrm{Pc}\right]: \mathrm{Mg}\left[(15 \mathrm{C} 5)(\mathrm{BuO})_{6} \mathrm{Pc}\right](179 \mathrm{mg}, 0.155$ $\mathrm{mmol})$ was dissolved in DMF $(40 \mathrm{ml})$. Solution was heated to $70{ }^{\circ} \mathrm{C}$ and conc. $\mathrm{HCl}(1 \mathrm{ml})$ was added and mixture was stirred for $1.5 \mathrm{~h}$ until $Q$-band of $\mathrm{Mg}$ complex $(681 \mathrm{~nm})$ vanished and split $Q$-bands of ligand (703 and $665 \mathrm{~nm}$ ) appeared. Then reaction mixture was poured into water $(200 \mathrm{ml})$, neutralized with aq. ammonia and filtered. Resulting green precipitate was washed with water, aq. EtOH, acetone and dried in vacuum. Phthalocyanine $\mathrm{H}_{2}\left[(15 \mathrm{C} 5)(\mathrm{BuO})_{6} \mathrm{Pc}\right]$ was obtained as a dark green powder $(145 \mathrm{mg}, 82 \%)$. UV-Vis $\left(\mathrm{CHCl}_{3}\right) \lambda_{\max } \mathrm{nm}(\lg \varepsilon): 703$ (5.21), 665 (5.13), 646 (4.72), 603 (4.46), 426 (4.61), 349 (4.99), 296 (4.84). MALDI TOF MS, $m / e$ : for $[\mathrm{MH}]^{+}-\mathrm{C}_{64} \mathrm{H}_{81} \mathrm{~N}_{8} \mathrm{O}_{11}$ calculated 1137.6, observed 1138.2.

\section{Results and Discussion}

\section{Synthesis of Mono-Crown-Substituted Phthalocyanine, $\mathrm{H}_{2}\left[(15 \mathrm{C} 5)(\mathrm{BuO}){ }_{6} \mathrm{Pc}\right]$}

Rational approach, often used for preparation of $\mathrm{A}_{3} \mathrm{~B}$ phthalocyanines - expansion of subphthalocyanines, ${ }^{\left[{ }^{[3]}\right]}$ cannot be applied in our case, because of strong Lewis acidity of boron halogenides, which precludes synthesis of $\left[(\mathrm{BuO})_{6} \mathrm{SubPc}\right] \mathrm{BX}$. Therefore, to synthesize soluble $\mathrm{A}_{3} \mathrm{~B}$-type mono-15-crown-5-substituted phthalocyanine $\mathrm{H}_{2}\left[(15 \mathrm{C} 5)(\mathrm{BuO})_{6} \mathrm{Pc}\right]$, we have chosen two-step approach, which implies statistical template condensation of two precursors - DCB15C5 and 4,5-dibutoxyphthalonitrile with subsequent demetallation of isolated labile magnesium complex. Application of magnesium ion as a template for this reaction was expected to increase the yield of phthalocyanines in comparison with non-template basepromoted cycloteramerization of phthalonitriles.

So, refluxing of mixture of 4,5-dibutoxyphthalonitrile (A) and DCB15C5 (B), taken in ratio 5:1 with 3 eq. of $\mathrm{Mg}(\mathrm{OAc})_{2}$ and $\mathrm{DBU}$ (6 eq.) in isoamyl alcohol afforded mixture, containing essentially $\mathrm{A}_{4}, \mathrm{~A}_{3} \mathrm{~B}$ and $\mathrm{A}_{2} \mathrm{~B}_{2}$ complexes, as evidenced by MALDI TOF MS (notably, the most intensive signals in mass-spectrum corresponded to adducts of corresponding magnesium phthalocyaninates with dihydroxybenzoic acid - DHB, used as a matrix, Figure 3).

We have found optimal conditions for chromatographic isolation of $\mathrm{Mg}\left[(15 \mathrm{C} 5)(\mathrm{BuO}){ }_{6} \mathrm{Pc}\right]$.Itturnedout thatapplication of alumina as a sorbent for column chromatography is not efficient - most of fractions were mixtures of complexes $-\mathrm{A}_{4}+\mathrm{A}_{3} \mathrm{~B}$ and $\mathrm{A}_{3} \mathrm{~B}+\mathrm{A}_{2} \mathrm{~B}_{2}$, as evidenced both by MALDI TOF MS and TLC. However, application of silica afforded efficient separation of relatively more polar target $\mathrm{A}_{3} \mathrm{~B}$ complex from less polar $\mathrm{A}_{4}$ after gradient elution by mixture of $\mathrm{CHCl}_{3}$ with $0-10 \mathrm{vol} \% \mathrm{MeOH}$. More polar $\mathrm{A}_{2} \mathrm{~B}_{2}$ were irreversibly absorbed on silica column. Thus, target magnesium complex $\mathrm{Mg}\left[(15 \mathrm{C} 5)(\mathrm{BuO})_{6} \mathrm{Pc}\right]$ was isolated in $41 \%$ yield. Its demetallation in the mixture of $\mathrm{DMF}$ and $\mathrm{HCl}$ afforded metal-free phthalocyanine in $82 \%$ yield.

\section{Aggregation of $\mathrm{H}_{2}\left[(15 \mathrm{C} 5)(\mathrm{BuO})_{6} \mathrm{Pc}\right]$ in Solution}

The aggregation of synthesized phthalocyanine in solution was investigated by means of concentration depended UV-Vis spectroscopic study in $\mathrm{CHCl}_{3}$. BouguerLambert-Beer law $-A=\varepsilon l C_{0}$ suggests that in the absence of aggregation the ratio of observed optical density $A$ to concentration of dissolved chromophore $\left(C_{0}, \mathrm{M}\right)$ and optical path length $(l, \mathrm{~cm})$ should be constant and equal to extinction coefficient of the monomeric compound $\left(\varepsilon_{\mathrm{m}}\right.$, $\left.1 \cdot \mathrm{cm}^{-1} \cdot \mathrm{mol}^{-1}\right)$. Deviation of plot in coordinates $\left(C_{0} v s \cdot A \cdot l^{-1} \cdot C_{0}^{-{ }^{-1}}\right)$ would evidence of aggregation of chromophore molecules. In this case, observed extinction coefficient $-\varepsilon_{\text {eff }}$ would contain contributions from both monomer and aggregate, depending on their ratio in solution, which in turn is driven by aggregation equilibrium constant, $K$.

Measurement of UV-Vis spectra of $\mathrm{H}_{2}\left[(15 \mathrm{C} 5)(\mathrm{BuO})_{6} \mathrm{Pc}\right]$ was performed in chloroform in range of concentrations 


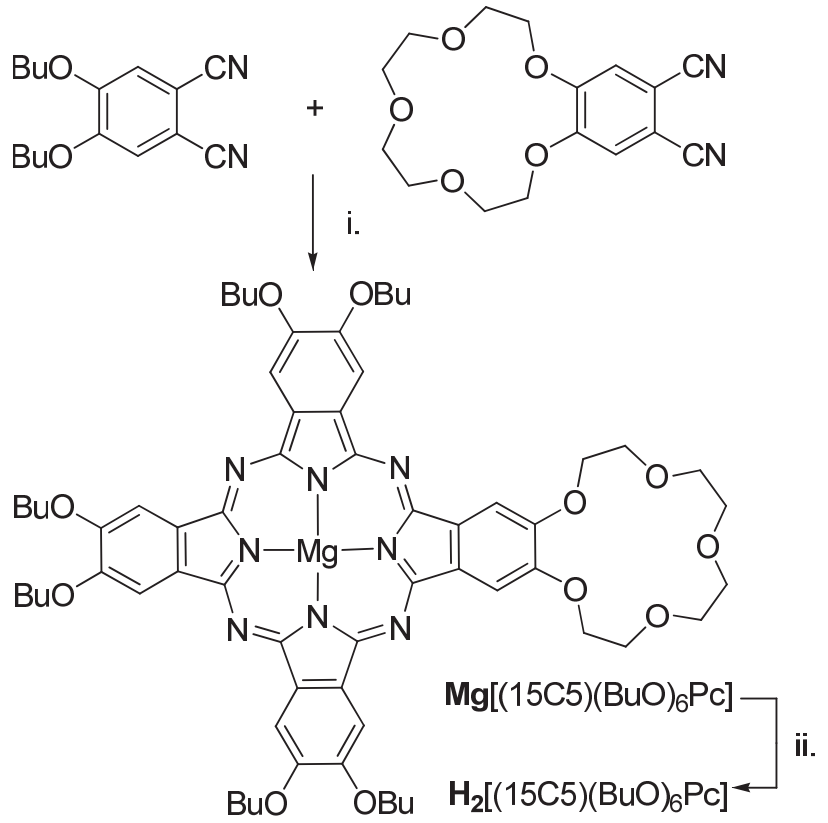

(a)

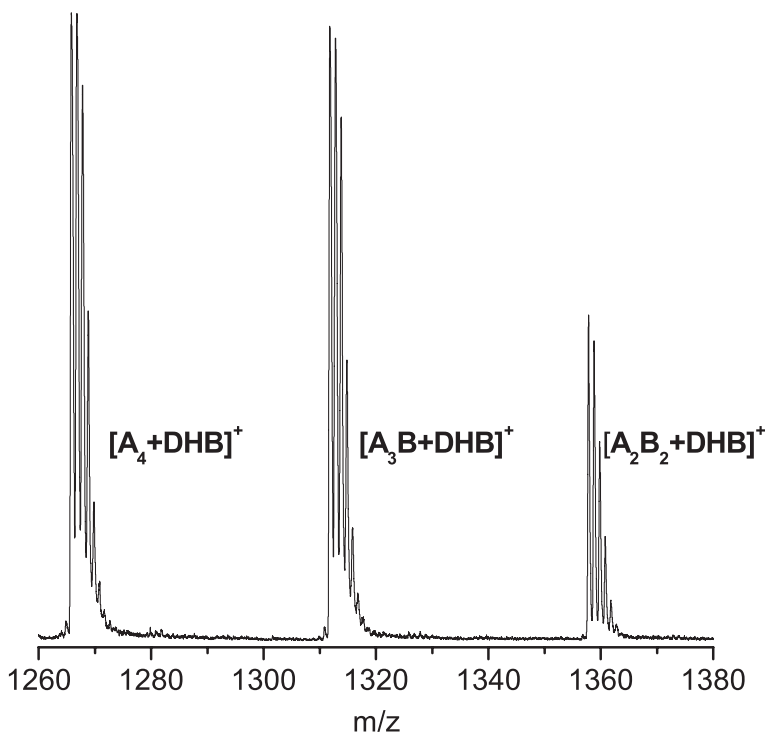

(b)

Figure 3. (a) - synthesis of $\mathrm{H}_{2}\left[(15 \mathrm{C} 5)(\mathrm{BuO}){ }_{6} \mathrm{Pc}\right] . i .-\mathrm{Mg}(\mathrm{OAc})_{2}$, DBU, $i-\mathrm{AmOH}, 150{ }^{\circ} \mathrm{C}, 24$ h., yield $-41 \%$; ii. $-\mathrm{HCl}, \mathrm{DMF}, 70{ }^{\circ} \mathrm{C}, 1.5$ h., yield $-82 \%$. (b) - fragment of MALDI TOF mass-spectrum of reaction mixture sample, obtained in synthesis of $\mathrm{Mg}\left[(15 \mathrm{C} 5)(\mathrm{BuO}){ }_{6} \mathrm{Pc}\right]$.
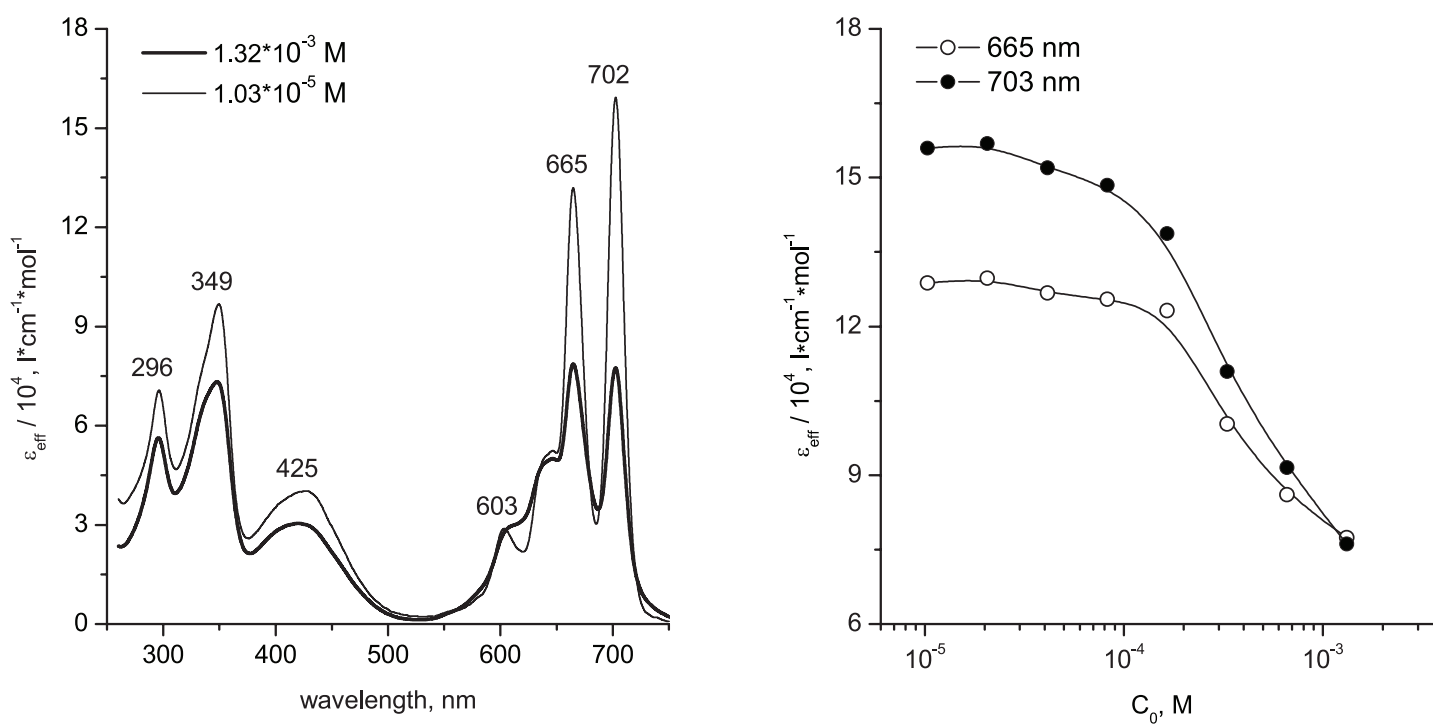

Figure 4. UV-Vis spectra of phthalocyanine $\mathrm{H}_{2}\left[(15 \mathrm{C} 5)(\mathrm{BuO}){ }_{6} \mathrm{Pc}\right]$ in chloroform at different concentrations and dependence of optical densities at $Q$-bands $v s$. concentration.

starting from $1.32 \cdot 10^{-3}$ to $1.03 \cdot 10^{-5} \mathrm{M}$. Solutions with intermediate concentrations were obtained by subsequent dilution, and spectra of samples were measured in $0.01-1 \mathrm{~cm}$ quartz cells.

Plotting $\left(C_{0} v s . \varepsilon_{\text {eff }}\right)$ for $Q$-bands at 703 and $665 \mathrm{~nm}$ evidenced that in most diluted solutions the values of $\varepsilon_{\text {eff }}$ become almost constant, however at $C_{0}>10^{-4} \mathrm{M}$ significant deviations from linearity are observed, and the relative intensities of $Q$-bands change (Figure 4). Altogether, it evidences of aggregation of phthalocyanine molecules with the formation of olygomeric species. $\left\{\mathrm{H}_{2}(15 \mathrm{C} 5)(\mathrm{BuO})_{6} \mathrm{Pc}\right\}_{n}$, where $n$-aggregation number.
Several approaches were proposed previously to study deviations from linearity in $\left(C_{0} v S . \varepsilon_{\text {eff }}\right)$ plots, most of them are based on assumption, that only one type of aggregates with singular value of aggregation number $n$ is formed within all studied concentration range. ${ }^{[32-35]}$

For example, the authors of paper ${ }^{[36]}$ suggest graphical analysis of UV-Vis spectra of series of concentrated solutions of chromophore molecules, based on the following equation:

$$
\lg \left[C_{0} \cdot\left(1-\frac{\varepsilon_{e f f}}{\varepsilon_{m}}\right)\right]=\lg (n \cdot K)+n \cdot \lg \left[C_{0} \cdot\left(\frac{\varepsilon_{e f f}}{\varepsilon_{m}}\right)\right]
$$


In accordance with this equation, the value $\lg \left[C_{0}\left(1-\varepsilon_{\text {eff }}\right.\right.$ ' $\left.\left.\varepsilon_{\mathrm{m}}\right)\right]$ plotted $v s . \lg \left[C_{0}\left(\varepsilon_{\text {eff }} / \varepsilon_{\mathrm{m}}\right)\right]$ should give a straight line with the slope, equal to $n$. Application of this approach to data, obtained for $\mathrm{H}_{2}\left[(15 \mathrm{C} 5)(\mathrm{BuO})_{6} \mathrm{Pc}\right]$ indeed gave straight lines for both $Q$-bands with slopes close to 2 , suggesting that upon aggregation of $\mathrm{H}_{2}\left[(15 \mathrm{C} 5)(\mathrm{BuO})_{6} \mathrm{Pc}\right]$ mostly dimeric species are formed. The values of $\varepsilon_{\mathrm{m}}$ were obtained by extrapolation of linear parts of $\left(C_{0} v s . \varepsilon_{\text {eff }}\right)$ plots to infinite dilution.

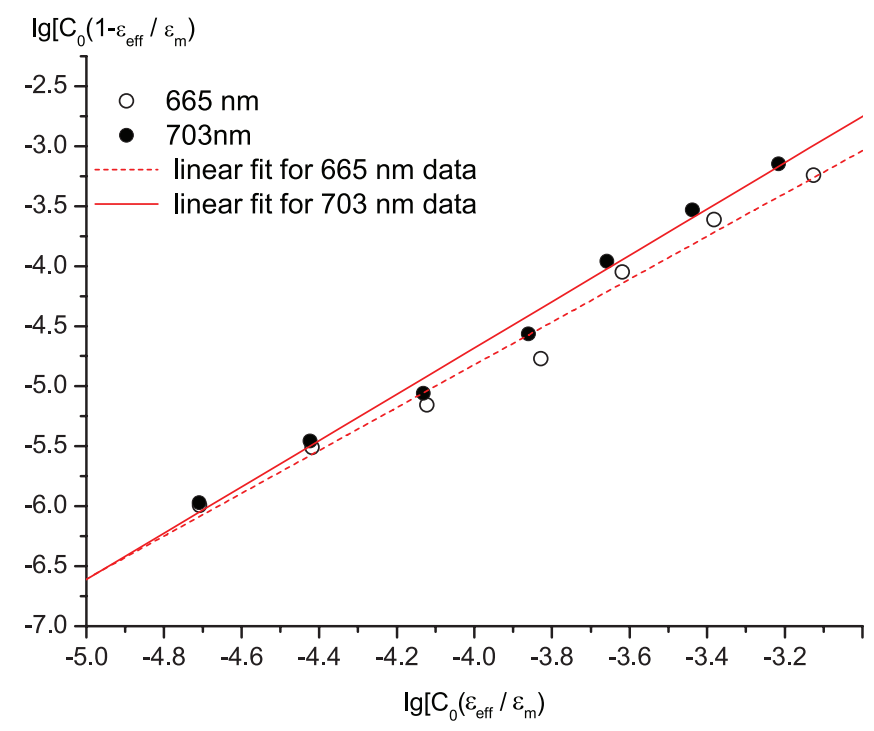

Figure 5. Graphical analysis of $\varepsilon_{\text {eff }}$ values for determination of aggregation number $n$, obtained for $Q$-bands at $665(n=1.78 \pm 0.11$, $\left.R^{2}=0.982\right)$ and $703 \mathrm{~nm}\left(n=1.92 \pm 0.08, R^{2}=0.991\right)$.

Equilibrium "2 Monomer $\leftrightarrows$ Dimer" is characterized by equilibrium constant $K(2)$ and material balance (3) which express correlations between concentrations of monomeric and dimeric forms of phthalocyanine in solution ([M] and $[D]$ respectively), namely:

$$
\begin{aligned}
& K=\frac{[D]}{[M]^{2}} \\
& C_{0}=[M]+2[D]
\end{aligned}
$$

Combination of these equations gives equation (4), which can be solved to find concentration of monomeric form. This square equation has two solutions, however only one of them - (5) has physical sense.

$$
\begin{aligned}
& 2 K[M]^{2}+[M]-C_{0}=0 \\
& {[M]=\frac{\sqrt{1+8 C_{0} K}-1}{4 K}}
\end{aligned}
$$

Optical density at certain wavelength is an additive value, which includes contributions from both monomer and dimer. Taking into account the equation of material balance (3), it can be expressed in the following way:

$$
A=\varepsilon_{m} \cdot[M]+\varepsilon_{d} \cdot[D]=\left(\varepsilon_{m}-\frac{\varepsilon_{d}}{2}\right) \cdot[M]+\frac{C_{0} \cdot \varepsilon_{d}}{2}
$$

Combination of equations (5) and (6) gives nonlinear equation (7), which expresses optical density as a function of concentration of dissolved compound. Other terms of this equation, namely equilibrium constant $K$ as well as extinction coefficients of monomer and dimer $\left(\varepsilon_{\mathrm{m}}\right.$ and $\varepsilon_{\mathrm{d}}$ respectively) are unknown, but they can be found by nonlinear regression analysis, therefore, we can reveal the UV-Vis spectra of monomer and dimer. Since changes in UV-Vis spectra, caused by aggregation, depend on mutual arrangement of chromophores within the dimer, its architecture can be proposed.

$$
A=\left(\varepsilon_{m}-\frac{\varepsilon_{d}}{2}\right) \cdot \frac{\sqrt{1+8 C_{0} K}-1}{4 K}+\frac{C_{0} \cdot \varepsilon_{d}}{2}
$$

To perform this analysis, we have used the $Q$-band region. The array of UV-Vis data for 23 wavelengths (from 600 to $710 \mathrm{~nm}$ with $5 \mathrm{~nm}$ step) was chosen. The concentrations were taken from $3.56 \cdot 10^{-4}$ to $1.81 \cdot 10^{-5} \mathrm{M}$ with subsequent two-times dilution (altogether $23 \times 7=161$ data points). The values of $\varepsilon_{\mathrm{m}}$ for 665 and $700 \mathrm{~nm}$ were fixed and all other parameters were varied until convergence was achieved. The calculated UV-Vis spectra of both monomer and dimer are given in Figure 6. The value of found equilibrium constant was $(1.38 \pm 0.15) \cdot 10^{3} \mathrm{M}$.

Characteristic feature of the calculated dimer spectrum is that it's $Q$-band is shifted with respect to $Q$-bands of monomer, evidencing of formation of dimer with parallel arrangement of transition dipoles ${ }^{[37]}$ - the so called H-dimer, whose formation is driven by stacking interactions between large aromatic systems of phthalocyanine molecules. ${ }^{[38]}$

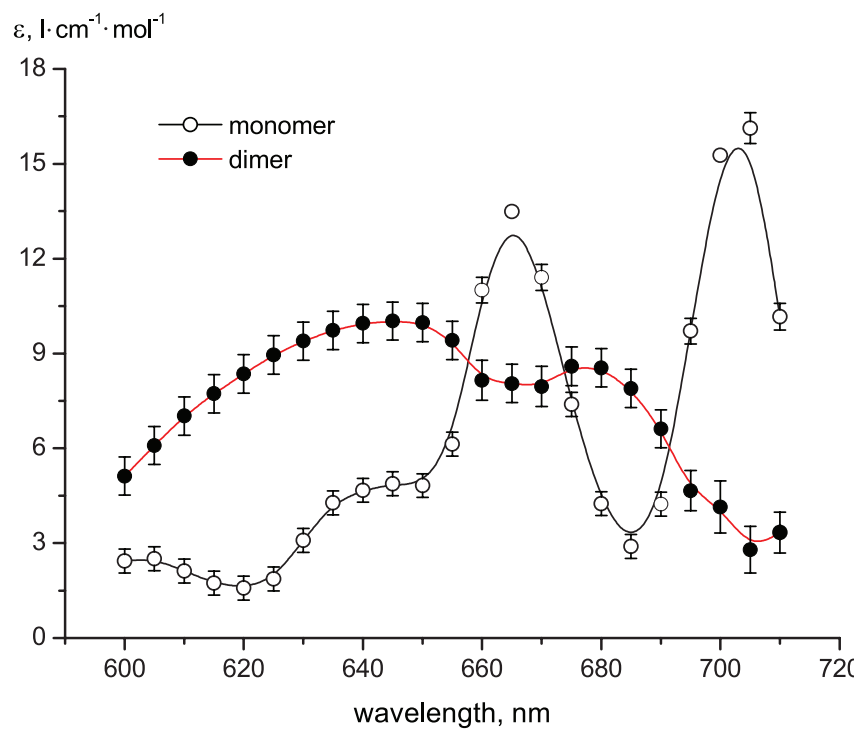

Figure 6. Calculated UV-Vis spectra of monomer and dimeric aggregate of $\mathrm{H}_{2}\left[(15 \mathrm{C} 5)(\mathrm{BuO})_{6} \mathrm{Pc}\right]$. 


\section{Cation-Induced Aggregation of $\mathrm{H}_{2}\left[(15 \mathrm{C} 5)(\mathrm{BuO})_{6} \mathrm{Pc}\right]$}

The above mentioned aggregation which occurs upon concentration rising is typical for phthalocyanines. ${ }^{[32]}$ However, in our case the presence of crown ether fragment in molecule affords one more way to control molecular assembly, namely, interaction with alkali metal ions. ${ }^{[2-4,18,39,40]}$

To perform studies of cation-induced aggregation of $\mathrm{H}_{2}\left[(15 \mathrm{C} 5)(\mathrm{BuO})_{6} \mathrm{Pc}\right]$, we have used spectrophotometric titration of the phthalocyanine dissolved in $\mathrm{CHCl}_{3} / \mathrm{CH}_{3} \mathrm{CN}$ (3:1 vol.) mixture by solution of $\mathrm{KOAc}$ in $\mathrm{CH}_{3} \mathrm{CN}$. Control experiment was made to make sure that addition of $\mathrm{CH}_{3} \mathrm{CN}$ itself does not induce aggregation of phthalocyanine.

Upon titration we observed decrease of intensity of $Q$-bands and growth of broad band with maximum at 644 $\mathrm{nm}$ (Figure 7). One set of isosbestic points is preserved throughout the titration process. The stoichiometry, found from titration curve, corresponds to binding of one potassium ion by two phthalocyanine molecules with the formation of supramolecular dimer. This becomes possible due to large size of potassium ion in comparison with the void of crownether ring.

To find stability constant, we applied ChemEqui software. ${ }^{[1,42]}$ This program utilized the method of non-linear least-squares for computations of equilibrium constants and related quantities from experimental results of various spectroscopic techniques. The equilibrium constants are calculated by best-fitting of the experimental data with an estimated chemical model of the equilibrium system. In our case it afforded the value of stability constant $\lg K=12.0$. Experimental titration curve was satisfactorily reproduced by result of simulation.

Dimer, formed by phthalocyanine in the presence of KOAc can be described as a pivot-joint, where molecular blocks can rotate around the axis, passing through $\mathrm{K}^{+}$and centers of crown ethers (Figure 8). Dihedral angle $\Theta$ can be used to describe geometry of such dimers.
Potassium-induced dimerization results in almost complete vanishing of initial $Q$-bands at 703 and 665 nm and appearance of hypsochromically shifted $Q$-band with maximum at $644 \mathrm{~nm}$. It means, that these dimers are characterized by significant intramolecular interactions, therefore, we can exclude expanded dimers with $90^{\circ}<\Theta<180^{\circ}$. Formation of eclipsed dimer with $\Theta=0^{\circ}$ can also be excluded, since such dimer should be characterized by relatively narrow and symmetrical Q-band, which was observed previously for $\mathrm{H}_{2}\left[(15 \mathrm{C} 5)_{4} \mathrm{Pc}\right] \cdot{ }^{[39]}$ Therefore, the formation of skewed dimer with partial overlap of aromatic systems with $0^{\circ}<\Theta<90^{\circ}$ can be proposed. Previously, similar system with pivot-joint geometry was studied on the example of low-symmetry heteroleptic lutetium complex - (Pc)Lu[(15C5)Pc]. ESR investigation of the dimer, formed in the presence of KOAc, suggested that dihedral angle $\Theta$ was around $25^{\circ} .{ }^{[20,21]}$

The UV-Vis spectrum of dimer, formed in the presence of KOAc is similar to the one, calculated for dimer, which is formed in concentrated solution of phthalocyanine (Figure 6), suggesting that these two dimers should have similar structure with partial overlap of aromatic systems. This conclusion is in agreement with previous results of analysis of UV-Vis spectra of phthalocyanine aggregates in terms of extended dipole model. ${ }^{[43]}$

Studies of aggregation of symmetrical tetra-crownsubstituted phthalocyanines $\mathrm{M}\left[(15 \mathrm{C} 5)_{4} \mathrm{Pc}\right] \quad(\mathrm{M}=2 \mathrm{H}$ and square-planar ions of $d$-elements $-\mathrm{Cu}^{2+}, \mathrm{Zn}^{2+}, \mathrm{Co}^{2+}, \mathrm{Ni}^{2+}$ ${ }^{[39,44]}$ as well as pyramidal trivalent ions, like $\mathrm{Ln}^{3+}$ or $\left.\mathrm{In}^{3+}\right)^{[45-}$ ${ }^{48]}$ evidence that their interaction with potassium ions can be described as a process with nonlinear cooperativity - binding of first cation by two receptor molecules results in formation of dimeric species, which are preorganized for stronger subsequent binding of next three cations with the formation of highly stable eclipsed dimers $-\left\{2 \mathrm{M}\left[(15 \mathrm{C} 5)_{4} \mathrm{Pc}\right] \cdot 4 \mathrm{~K}^{+}\right\}$. [22,40] The investigation, performed herein, supports this mechanism - indeed, the dimer, where phthalocyanine molecules are linked just with one potassium ion, already

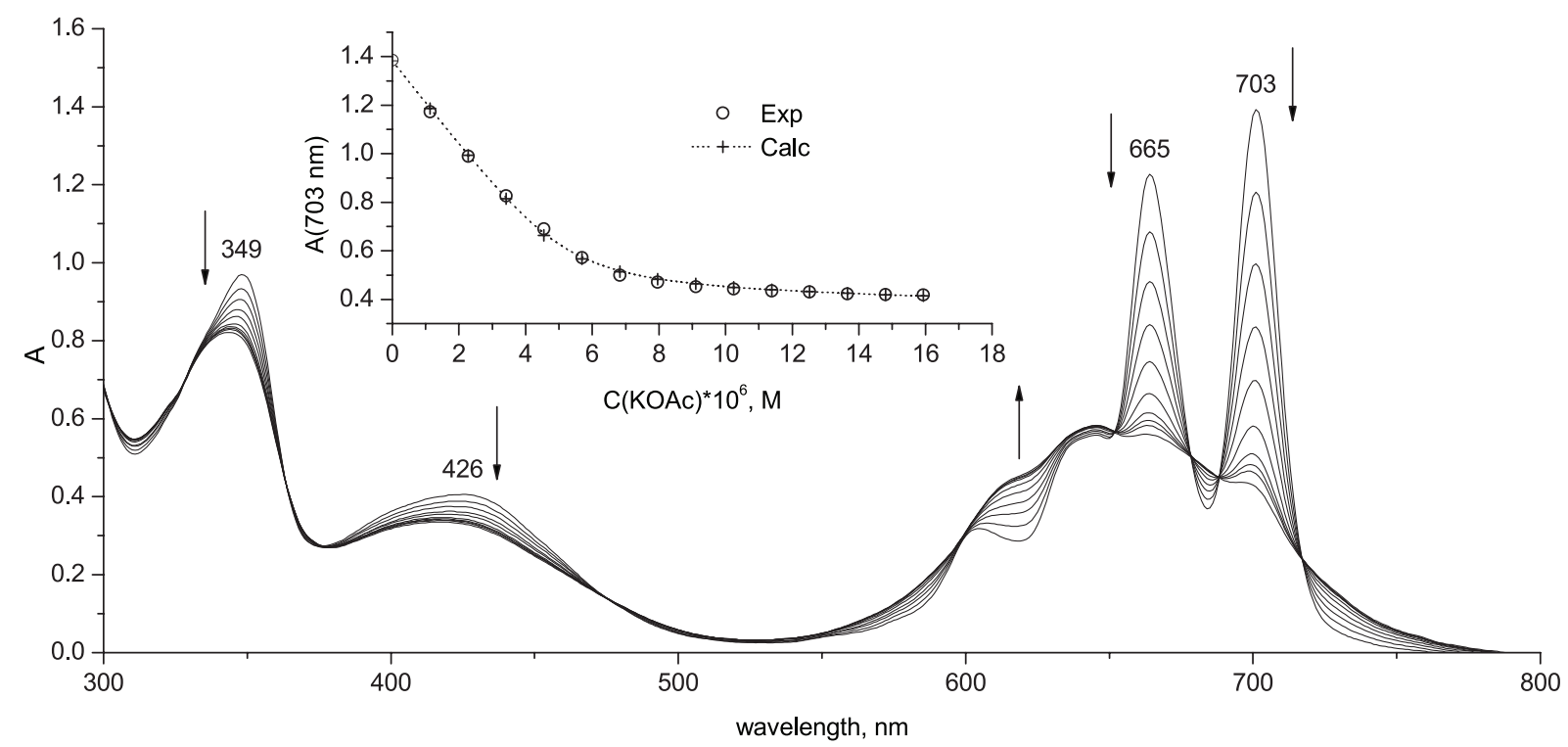

Figure 7. Changes in UV-Vis spectrum of $\mathrm{H}_{2}\left[(15 \mathrm{C} 5)(\mathrm{BuO})_{6} \mathrm{Pc}\right]$ in $\mathrm{CHCl}_{3} / \mathrm{CH}_{3} \mathrm{CN}(3: 1$ vol.) upon titration with solution of $\mathrm{KOAc}$ in $\mathrm{CH}_{3} \mathrm{CN}$. Inset shows titration curve plotted for optical density of $Q$-band at $703 \mathrm{~nm}$. Calculated curve corresponds to equilibrium constant $\lg K=12.0$. 


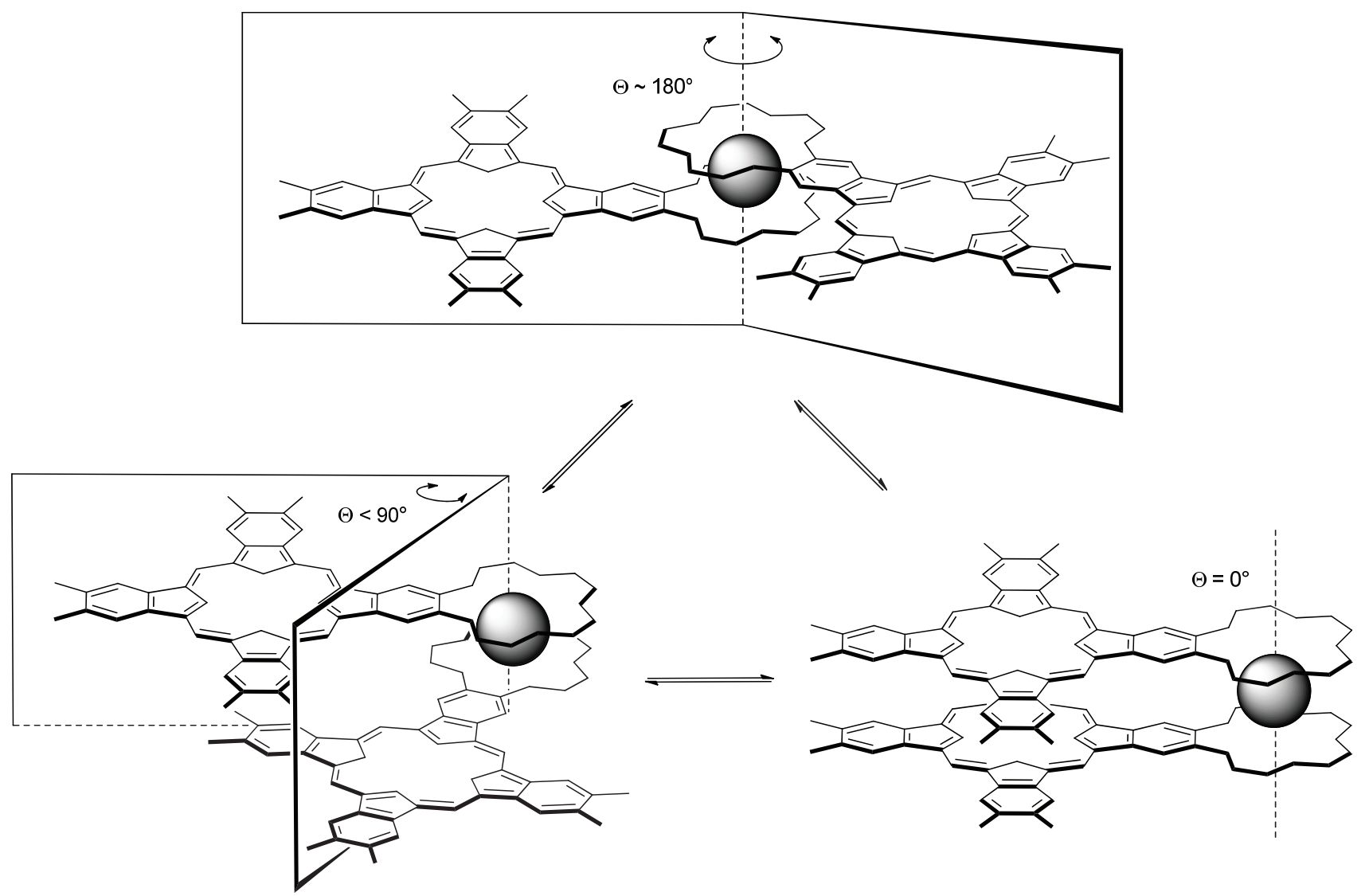

Figure 8. Schematic representation of possible conformations of supramolecular dimers, formed by $\mathrm{H}_{2}\left[(15 \mathrm{C} 5)(\mathrm{BuO}){ }_{6} \mathrm{Pc}\right]$ in the presence of KOAc.

has conformation close to eclipsed. This is due to synergetic effect of ion binding and intramolecular stacking interaction, which results in formation of supramolecular dimer with high stability constant.

Acknowledgements. This work was supported by Russian Foundation for Basic Research (grant 14-03-00977).

\section{References}

1. Wöhrle D., Schnurpfeil G., Makarov S.G., Kazarin A., Suvorova O.N. Macroheterocycles 2012, 5, 191-202.

2. Gorbunova Y.G., Lapkina L.A., Tsivadze A.Y. J. Coord. Chem. 2003, 56, 1223-1232.

3. Tsivadze A.Y. Russ. Chem. Rev. 2004, 73, 5-23.

4. Gorbunova Y.G., Martynov A.G., Tsivadze A.Y. In: Handbook of Porphyrin Science (Kadish K.M., Smith K.M., Guilard R., Eds.), World Scientific Publishing, 2012, Vol. 24, pp. 271-388.

5. Selector S.L., Arslanov V.V., Gorbunova Y.G., Raitman O.A., Sheinina L.S., Birin K.P., Tsivadze A.Y. J. Porphyrins Phthalocyanines 2008, 12, 1154-1162.

6. Grishina A.D., Gorbunova Y.G., Zolotarevsky V.I., Pereshivko L.Y., Enakieva Y.Y., Krivenko T.V., Savelyev V., Vannikov A.V., Tsivadze A.Y. J. Porphyrins Phthalocyanines 2009, 13, 92-98.

7. Grishina A.D., Konnov F.Y., Gorbunova Y.G., Enakieva Y.Y., Pereshivko L.Y., Krivenko T.V., Savelyev V., Vannikov A.V., Tsivadze A.Y. Russ. J. Phys. Chem. A 2007, 81, 982-989.

8. de la Torre G., Claessens C.G., Torres T. Eur. J. Org. Chem. 2000, 2000, 2821-2830.
9. Rodríguez-Morgade M.S., de la Torre G., Torres T. In: The Porphyrin Handbook (Kadish K.M., Smith K.M., Guilard R., Eds.), New York: Elsevier, 2003, Vol. 15, pp. 125-160.

10. de la Torre G., Bottari G., Hahn U., Torres T. In: Functional Phthalocyanine Molecular Materials (Jiang J., Ed.), Berlin, Heidelberg: Springer Berlin Heidelberg, 2010, Vol. 135, pp. $1-44$.

11. Martínez-Díaz M.V., Rodríguez-Morgade M.S., Feiters M.C., van Kan P.J.M., Nolte R.J.M., Stoddart J.F., Torres T. Org. Lett. 2000, 2, 1057-1060.

12. Guldi D.M., Ramey J., Martínez-Díaz M.V., de la Escosura A., Torres T., Da Ros T., Prato M. Chem. Commun. 2002, 2774-2475.

13. Martínez-Díaz M.V., Fender N.S., Rodríguez-Morgade M.S., Gómez-López M., Diederich F., Echegoyen L., Stoddart J.F., Torres T. J. Mater. Chem. 2002, 12, 2095-2099.

14. Ayhan M.M., Singh A., Hirel C., Gürek A.G., Ahsen V., Jeanneau E., Ledoux-Rak I., Zyss J., Andraud C., Bretonnière Y. J. Am. Chem. Soc. 2012, 134, 3655-8.

15. Kopecky K., Šatinský D., Novakova V., Miletin M., Svoboda A., Zimcik P. Dyes Pigment. 2011, 91, 112-119.

16. Stuzhin P.A., Pimkov I.V., Ul'-Khak A., Ivanova S.S., Popkova I.A., Volkovich D.I., Kuz'mitskii V.A., Donzello M.-P. Russ. J. Org. Chem. 2007, 43, 1854-1863.

17. Gorbunova Y.G., Lapkina L.A., Martynov A.G., Biryukova I.V., Tsivadze A.Y. Russ. J. Coord. Chem. 2004, 30, 245-251.

18. Martynov A.G., Gorbunova Y.G. Inorg. Chim. Acta 2007, 360, 122-130.

19. Martynov A.G., Zubareva O.V., Gorbunova Y.G., Sakharov S.G., Nefedov S.E., Dolgushin F.M., Tsivadze A.Y. Eur. J. Inorg. Chem. 2007, 4800-4807.

20. Ishikawa N., Kaizu Y. Chem. Lett. 1998, 1998, 183-184.

21. Ishikawa N., Kaizu Y. Coord. Chem. Rev. 2002, 226, 93-101. 
22. Sheng N., Li R., Choi C.-F., Su W., Nicholson M.M., Cui X., Yoshida K., Kobayashi N., Jiang J. Inorg. Chem. 2006, 45, 3794-3802.

23. Sheng N., Zhang Y., Xu H., Bao M., Sun X., Jiang J. Eur. J. Inorg. Chem. 2007, 3268-3275.

24. Cai X., Sheng N., Zhang Y., Qi D., Jiang J. Spectrochim. Acta, Part $A$ 2009, 72, 627-635.

25. Musluoglu E., Gürek A., Ahsen V., Gül A., Bekâroğlu Ö. Chem. Ber. 1992, 125, 2337-2339.

26. Xu H. Mater. Sci. Eng., C 1999, 10, 71-74.

27. Li X.Y., Chen Y.L., Xu H. Chin. Chem. Lett. 1999, 10, 167-170.

28. Sauer T., Wegner G. Mol. Cryst. Liq. Cryst. 1988, 162B, $97-$ 118.

29. Gorbunova Y.G., Komarova O.Y., Demin S.V., Meshkov C.V., Tsivadze A.Y. Russ. J. Coord. Chem. 1997, 23, 516-519.

30. Fulmer G.R., Miller A.J.M., Sherden N.H., Gottlieb H.E., Nudelman A., Stoltz B.M., Bercaw J.E., Goldberg K.I. Organometallics 2010, 29, 2176-2179.

31. Kobayashi N., Ishizaki T., Ishii K., Konami H. J. Am. Chem. Soc. 1999, 121, 9096-9110.

32. Snow A.W. In: The Porphyrin Handbook (Kadish K.M., Smith K.M., Guilard R., Eds.), New York: Academic Press, 2003, Vol. 17, pp. 129-176.

33. Leenson I.A. J. Chem. Educ. 1986, 63, 437-441.

34. Tai S., Hayashi N. J. Chem. Soc. Perkin Trans. 2 1991, 1275.

35. Zelina J.P., Njue C.K., Rusling J.F., Kamau G.N., Masila M., Kibugu J. J. Porphyrins Phthalocyanines 1999, 3, 188-195.
36. Mataga N. Bull. Chem. Soc. Jpn. 1957, 213.

37. Kasha M., Rawls H.R., El-Bayoumi M.A. Pure Appl. Chem. 1965, 11, 371-392.

38. Hunter C.A., Sanders J.K.M. J. Am. Chem. Soc. 1990, 112, 5525-5534.

39. Kobayashi N., Lever A.B.P. J. Am. Chem. Soc. 1987, 109, 7433-7441.

40. Martynov A.G., Zubareva O.V., Gorbunova Y.G., Sakharov S.G., Tsivadze A.Y. Inorg. Chim. Acta 2009, 362, 11-18.

41. http://www.vpsolovev.ru/programs/.

42. Solov'ev V.P., Baulin V.E., Strakhova N.N., Kazachenko V.P., Belsky V.K., Varnek A.A., Volkova T.A., Wipff G. J. Chem. Soc. Perkin Trans. 2 1998, 1489-1498.

43. Sakakibara Y., Saito K., Tani T. Jpn. J. Appl. Phys. 1998, 37, 695-699.

44. Sielcken O.E., Van Tilborg M.M., Roks M.F.M., Hendriks R., Drenth W., Nolte R.J.M. J. Am. Chem. Soc. 1987, 109, 42614265.

45. Lapkina L.A., Larchenko V.E., Popov K.I., Tsivadze A.Y. Russ. J. Inorg. Chem. 1998, 43, 1747-1750.

46. Lapkina L.A., Larchenko V.E., Popov K.I., Tsivadze A.Y. Russ. J. Inorg. Chem. 2001, 46, 84-88.

47. Lapkina L.A., Gorbunova Y.G., Gil D.O., Ivanov V.K., Konstantinov N.Y., Tsivadze A.Y. J. Porphyrins Phthalocyanines 2013, 17, 564-572.

48. Lapkina L.A., Gorbunova Y.G., Larchenko V.E., Tsivadze A.Y. Russ. J. Inorg. Chem. 2003, 48, 1053-1061. 